Ewa Murawska

Pomerania Academy in Słupsk

\title{
Teachers' everyday reality, as seen from the perspective of their own narratives. Selected threads of theoretical approaches and autobiographical texts
}

\begin{abstract}
Scientific interest in everyday life is mainly present in sociology but also in philosophy, psychology, pedagogy and increasingly also in pedeutology. In this paper, I relate to personal, everyday experiences of teachers exercising their role in the contemporary conditions of social and educational change. The paper features thought-provoking statements made by teachers on their own professional activity.
\end{abstract}

Key words: everyday life, teacher, professional experience

\section{INTRODUCTION}

Let me begin with a rather banal statement that a significant dimension of teacher's activity and the essence of their profession is to spread comprehensive, theoretical knowledge as well as to develop pupils' practical skills that are to be used in various fields of science and areas of activity. Teachers' functions change and constantly evolve, and nowadays their role is not merely limited to the transmission of knowledge in a more or less organised form. The complex, constantly changing socio-economic reality we live in and the trends noticeable in the contemporary world require different teaching methods than 
those hitherto in use. The new way must simply involve knowledge transfer and the development of skills that are deeply embedded in the new reality. A modern teaching method should be used instead of the current teaching model which remains somehow divorced from practice, focused mainly on equipping pupils with the knowledge of lexis. Contemporary teachers are not only to impart knowledge, but they also need to be counselors, they have to support their pupils in the acquisition and the discovery of new ideas and skills. The role of modern teachers is to introduce their pupils to the world of reflective, specific knowledge, i.e. to inspire them to perform comprehensive analyses and interpretation of information and events, as well as to encourage them to independent evaluation of acquired knowledge and skills, because, as M. Olejniczak aptly describes: "[...] it is no longer the access to information and knowledge in the field of education that is a problem, but the overload along with lack of skills to evaluate information" (Olejniczak, p. 207). Moreover, it is vital to emphasise that teachers with their numerous, complex tasks of educational and didactic nature, are representative of tomorrow's culture in their schools and in the course of extracurricular activities. It is largely because the future of education and training, as well as social activity of children and young people are facing inevitable, but unpredictable changes, depending on teachers themselves. It can be assumed that in the long term perspective, teachers' educational activities will indirectly determine the civilisational, cultural and social future of pupils' hometown and homeland, all the above adding to the professional role of contemporary educators.

Furthermore, it must be stressed that teachers are as much educators and didactic workers as tutors. Together with parents and pees, teachers become the most influential educational entities. Therefore, the teaching profession is undoubtedly one of the most beautiful and fascinating, but at the same time it entails enormous responsibility for other individuals, their intellectual development and their spiritual, emotional and physical security. The most distinguishable feature of this occupation is that it not only determines pupils' educational circumstance at present, but also the future of subsequent generations, and - as a result - to a certain extent it also determines both the culture of everyday reality and the value of the present. Teacher's is a profession of a constant dialogue, exchanging experiences, achieving ultimate goals and appreciating the highest values. It is always viewed from the humanistic perspective and based on interpersonal relations, which also involve emotions. Understanding that cooperation with others is undoubtedly the core of their 
profession, teachers work in difficult, always outstanding and unique conditions. It is this interpersonal relation that makes them react in situations which are always exceptional and impossible to predict.

Among many studies concerning the teaching profession and its role in the society, it is easy to notice that those which relate to teachers' duties and responsibilities from a normative perspective outnumber other approaches. This is a perspective that highlights expectations from teachers to comply with all the regulations as well as "the importance of the regulations themselves", with which they should identify. However, the reality shows that while facing the nature of their profession, being full of contradictions and inconsistencies, teachers often feel uncomfortable and frustrated "in their normatively overloaded role". Thus, it is impossible to meet all the requirements from many subjects in the educational system (the requirements are often self-contradictory by nature), nor to fulfil all the roles outside the working environment at the same time. This fact becomes a true inspiration for a deeper insight into this profession, regarding it from teachers' very personal perspective, as attested by their autobiographical narrations.

It should be emphasised that the pedeutologic narration on which I base my reflections, is one of many perspectives to describe teachers' worlds, one of many proposals how to become familiarised with all the vicissitudes of their professional life, one of many possible narratives in education. Through the analysis of teachers' narratives, one can attempt to identify what constitutes the rhythm of "an average teacher's" working life. One can seek to answer the question: what experiences, sensations and emotions mark their daily life?

\section{(UN)USUAL LIFE OF THE TEACHER AS A WAY TO ANALYSE THEIR PROFESSIONAL ACTIVITY}

Taking into consideration the etymology of the term everyday life, placed somewhere between phenomenology and sociology of everyday life, one can treat it as an analytical category of high, cognitive potential. So far, the concept of everyday life has been associated with monotony, boredom, repetition and obviousness. This dullness of everyday life, attributed to mundane tasks and experiences, has always been contrasted with the colourful uniqueness of "a holy day". Everyday life has not been treated as an attractive subject matter. 
It has been the area of human experience which does not bring up further questions and does not require profound reflection. To view "a holiday experience" as a suspension of everyday activities, as a break, an intermission between the acts of life, a longed-for period of relief from everyday duties which often arouse negative emotions, a time for recuperation, is quite a different perspective" (Rutkowiak, 2003, p. 73). It seems that the contemporary pace of life, its volatility, risk, unpredictability being an experience of every single person and the whole community as well, are changing the image of what we refer to today as "everyday life". A holiday experience becomes then a part of everyday life that penetrates our everyday experience, i.e. the sacrum of a holiday breaks the profanum of everyday life'.

In pedeutology, this noticeable turn towards everyday life is an example of changes taking place in the humanities. Moreover, it is a sign of a kind of "a paradigmatic breakthrough" in human sciences (also in pedeutology). In this kind of research, it might be valuable to draw on new epistemologies which also provide a different kind of insight into this subject (including ontological and methodological aspects). Undoubtedly, one should also refer to a vast amount of scientific literature on the topic of "everyday life", defined as "the life experienced", "the lifeworld(s)" or "the habitat". Although these concepts are not treated as synonyms, even by their authors (Edmund Husserl and Alfred Schütz), it is important to demonstrate and emphasise their theoretical and methodological potential in reflecting on the image of teachers' everyday working life ${ }^{2}$. Phenomenological references are derived from Edmund Husserl's and Max Scheler's concept of "the life experienced" in which it is defined that the natural attitude that we consciously adopt is dominated by common and scientific knowledge of the world that we live in (Schütz, 1984, p. 146). Discovering some basic structures of individuals' consciousness is a method to gain true knowledge of social reality. The second reference is based on the belief that before one starts doing research on everyday life, one should consider a question of relationship between the meanings given by individuals and the meanings existing in the culture in which these individuals

I elaborate on this topic in my work Nauczycielska (nie)codzienność. Mikrospojrzenie $w$ makrosprawach, [in:] I. Surina, E. Murawska, D. Apanel, G. Durka, Edukacja w obliczu przemian społecznych, Wydawnictwo Adam Marszałek, Toruń 2013, pp. 72-118.

2 My inspiration to discuss this issue was inspired by A. Schütz's and E. Husserl's works, as well as reflections of A. Giddens, E. Goffman and P. Bourdieu. 
function (Weber, 1985). As regards the subject of my interest, one may ask, in the light of the assumptions mentioned above, to what extent the meanings assigned to particular phenomena of teachers' everyday life are their own and to what extent they belong to the social environment in which they live (mainly to the educational space they operate in)?

Discovering the nature of meanings can be made in the following dimensions:

- intrapersonal (within one's inner self);

- interpersonal;

- existing within the society;

- being in relation with the symbolic, material, natural and technical world (Bhaskar, 2010, p. 109).

In my analysis, the first three dimensions are of the highest importance in teachers' lives, i.e. being in relationships with others, building attitudes towards themselves (including self-awareness, self-knowledge, self-analysis) and functioning in the educational space which remains an integral part of a wider social space. According to Schütz, the category of "everyday life" and the "lifeworld" mean the world which assumes a structure of socially shared meanings and arrangements made throughout the history, which we are then to interpret. It might be stated that "the lifeworld" is built on the experience of our predecessors, of our contemporaries and of our own, all the above being a kind of our "basic knowledge". This world is like "footing", it provides a sense of familiarity which means that we know what to do, and we know that the patterns of our behaviour have been already established (Anthony Giddens calls this fact "routinization", 2003, p. 102). Thus, 'the lifeworld' "from the very beginning is not - as Schütz claims it - the private world of a particular individual, but an inter-subjective world that we all share" (Schütz, 2008, p. 18). This fact, however, does not denote a totality or unification of experience, as each person lives "everyday life" individually and in their own way, finding their own place in the world through biographical experiences of making right choices and giving their own interpretation of events, facts and feelings. The choices that we make in certain situations are derived from communicative experiences in which our knowledge and confidence about reliability are built up (Schütz, 2008, p. 26). Consequently, if one would like Schütz to answer the question why it is vital for pedagogical reflections to define and describe "the lifeworld" first, his reply would be "»the lifeworld $\ll[\ldots]$ is an archetype of our experience of reality” (Schütz, 2008, p. 37). Thus, for teachers, but for 
pupils and their parents as well, in order to let the educational activity facilitate a better recognition of their own situation, it is necessary to draw attention to this daily dimension of educational activity itself and take into account the pedagogical discourse of common knowledge ${ }^{3}$.

Teachers' experiences and initiatives are part of the educational world (Murawska, 2014, pp. 99-109), i.e. their world "is just like any other limited field of meaning, the real world of objects and events which they can influence through their own educational activities. It is characterised by a specific level of consciousness, by a determined structure of time, by their specific experience of their inner selves, and a form of socialisation” (Murawska, 2014, p. 25). Therefore, it is a microcosm embedded in the space of everyday life, individually perceived and experienced by each teacher. Since each teacher assigns subjective meanings and sees the world in a different way, we must deal with a multiplicity of different versions of the educational world. The variety of educational worlds results from the fact that they are built on different foundations: teachers' own biographies, knowledge, individual experiences, the potential of past and future intentions, beliefs and expectations. One must also add the foundations of the teaching profession and teachers' experience of their selves in this profession. "Teachers' educational world [...] is a world inhabited by humans, a world explored, described, transformed, constructed and valuable. It is a world in which $\gg$ opening up $\ll$ and sharing educational experience take place through language. It is, therefore, an inter-subjective world" (Malinowska \& Jabłońska, 2010, p. 30). This means that teachers' educational world is constructed by means of cooperation and coexistence with other teachers who constitute a fellowship that shares experiences, experiences the same problems, values and objectives and co-participates in various types of educational situations. The important areas of teacher's everyday life "[ $[.$.$] serve both as$ a scheme of interpretation for each teacher, and - at the same time - create a universe of discourse within teaching communities. You can therefore say, as Alfred Schütz claims, that teachers performing the same professional roles are connected through common influences and work, and they understand themselves and others" (Schütz, excerpted from: G. Ritzer, 2004, p. 287). For this reason, all teachers find similar meanings, similar ways of interpreting phenomena and understanding their meaning, establish similar binding standards, all

3 Schütz lists the following features of common knowledge: "translatability of perspectives", "social distribution of knowledge" and "lifeworld of knowledge" (Schutz, 2008, p. 13). 
this being an agreement upon the assumed and accepted version of reality. The educational world "is part of the social world which is embodied in the multiplicity and diversity of individual and collective worlds that are constantly being created. It is (re)constructed in everyday educational practices in which teachers, being involved in the educational process, give shape and value to what, in their minds, teaching is" (Malinowska, Jabłońska, 2010, p. 32).

For the last several years, there have been attempts to look at teachers from the perspective of their subjective, individual experiences. It has made it possible, I hope, along with own my research, to reach out to ordinary, everyday life, to take into account life experience, personal perspectives of perception and evaluation of the world in order to (re)construct the "unified" image of modern teachers and recognise the versions of reality that are accepted by them. My personal inspiration, and an important reason for seeking "a new perspective" to describe teachers' roles, was the fact that in pedeutology the image of this role is "normatively overloaded". This, in practice, leads to a growing dissonance between what is expected of teachers and the description of their figures as representatives of the whole teaching community, as compared with the possibility to meet these expectations and the real image of the teacher "immersed in school reality". In this context, an important query to be asked is that about everyday life perceived by teachers themselves, about their identity and the narrational understanding of this identity". This identity seen "as an ability to sustain a narrative" which must be "a constantly reconstructed, constructed and (de)constructed tale of $>>\mathrm{I}<<$ " (Nowak-Dziemianowicz, 2012 , p. 9) and which demands from pedeutologists to open up to the subjective lifeworlds, to teachers' personal stories, to the experience lived. While asking the question about the essence of the social/educational reality, at the same time we investigate the ways of identifying this reality and the possibility of insight into the subjective experience of its participants. It is also a question of how the subject (in this case: the teacher) is present in the narratives, and how one can meet and understand the subject in this reality. The search for the answers to these questions is linked with the need to choose a form of philosophical perspective, and when choosing the orientation of the narrative, we must assume that the world studied in social sciences is a world that is already substantiated through everyday life acts ${ }^{4}$. These assumptions are derived

4 I elaborate on this and I analyse the empirical material which includes teachers' autobiographical narratives in the upcoming book Nauczyciel - osoba $w$ drodze. Codzienność zawo- 
from phenomenology and allow one to capture the essence of the world experienced, the lifeworld, as Habermas or Husserl call it. The basis for this approach is in the belief that the human world is an inter-subjective world of culture, and it "takes form of narrative, being a constantly decoded, interpreted story about oneself and about one's relations with the world" (NowakDziemianowicz, 2012, p. 26). From phenomenological-hermeneutic perspective, it is possible to have an insight into the subjective world of man, into the meaning hidden in their biography. We are given the opportunity to immerse in the world of values and extract experiences so as to grasp their meaning.

\section{REFLECTIONS OF TEACHERS' EVERYDAY LIFE}

To illustrate teachers' everyday life, let us focus upon certain selected fragments of narration ${ }^{5}$ provided by professionally active teachers. In them, teachers reveal (un)common experiences, emotions, reflections and their "states of mind". The cognitive potential of those autobiographic stories provides, above all, an opportunity to look at teachers' work from their own personal perspective, i.e. their everyday experience. It is also an attempt to face the complexity and multitude of the teachers' worlds. Thus, it appears worthwhile to "visit" those worlds and to experience the diversity of their everyday experiences. I have decided to present only three "landscapes" of teachers' everyday life ${ }^{6}$, which serve merely as an illustration, and as such, they constitute exemplification of teachers' everyday experiences and the meanings they attach to their profession. This, in short, is what I consider of greatest significance: the experiences of working teachers recorded and presented in their narratives - resulting

dowa nauczycieli w perspektywie narracji autobiograficznych (it will be published this year by Wydawnictwo Adam Marszałek).

5 These are merely a few selected quotations from a wide set of texts authored by teachers training at the graduate and post-graduate level at Pomeranian University in Słupsk. A report from this research, seen from philosophical and methodological perspective (strategies of qualitative studies), will be included in a currently prepared book by E. Murawska: Nauczyciel - osoba $w$ drodze. Codzienność..., op. cit.

6 These are three selected works (from all 58 works collected during this academic year I randomly chose only three "scenarios" of everyday reality of school written at my request by teachers studying at Pomeranian University in Słupsk). 
from reflections regarding their professional careers, relations with pupils and their parents, other members of the teaching staff, as well as individual experiences subjected to in-depth analyses which form essential self-knowledge and prepare for self-analyses concerning complex issues and conditions related to the essence of being a teacher. A point of reference is constituted by a briefly outlined theoretical perspective forming a set of basic issues regarding normative perception of teachers' roles and a short presentation of the potential possibilities, which, employing hermeneutic-phenomenological approach, are provided by "the pedeutology of daily life". Thus":

N1: About her initiation into the profession, relations within the teaching staff as well as her uneasy experiences, the first narrator (Justyna, 6 years of teaching practice, a single mother of one son) wrote the following: [...] The first year of my work consisted in working with 6-year-old children - at the pre-school level. As a trainee teacher, I was immediately thrown into deep waters for I got children from pathological families (in which alcohol was the biggest problem). Most children were neglected, their vocabulary was poor and, at the moment of enrolment, it was clear that they were unfamiliar with most toys. Some of them drew with crayons for the very first time in their lives. There was clearly a lot of work ahead of me, so instead of implementing pre-school syllabus and introducing letters, during the first month, I focused on integrating the group in order to set ground rules and to show those children relations which were different from those they had witnessed at home. On numerous occasions, the kids argued, screamed, verbally abused one another - there were even cases of fights. I decided to introduce a number of integrating games aiming to help those kids learn about themselves and one another. They were also supposed to teach them how to solve problems, search for ways out of difficult situations and help their teamwork skills. During one week - in the course of various activities - we established the rights and responsibilities of the members of our group. Each child fulfilled an essential function in it - there was a group administrator, a deputy, a secretary, children in charge of different interest clubs, a judge and the jury [...]. The effect of that month's work culminated in staging a play: "To the rescue of Earth" which we prepared together - including making clothes and decorations. We performed in front of all the pre-school groups - parents were also invited. Some of those parents were virtually shocked: they

7 To ensure the authors' anonymity - for the purpose of this analysis I provided symbols $\mathrm{N} 1,2,3$ and fictitious names for those authors ( $\mathrm{N}$ - narrator). 
witnessed their own children in completely different roles. The kids had learned all their lines by heart - even though they hadn't learned them at home. And they spoke them wonderfully, with joy. Many parents emphatically thanked me that I was able to see their children's value - that despite their problems with diction they chose to perform anyway. They were even thankful that I made the effort to organise the stage clothes. At the first formal meeting with parents, the attendance amounted to 100 per cent, some parents came in couples. I introduced myself to them, admitted to my age and lack of experience in raising my own child (for I had none). I emphasized the fact that I wasn't there to judge anyone or be overbearing. I also said I was sorry that some of them had dismissed me at the first glance without even granting me any opportunity to prove myself - instead saying something to the extent of "such a rookie's going to teach our kids and be judgemental". I told them that I had completed my studies and had theoretical knowledge - and if we combine it with their experience, we can achieve success. I added that I felt responsible for those children and I wanted them to grow up to be responsible, respected children who would find their own way in the world - but that without their help there was little I could do.

This honesty, empathy and understanding helped me to earn the children's trust as well as gain the parents' willingness to cooperate. They gladly participated in open classes, they came with their problems, borrowed my books on children's education and upbringing. On numerous occasions they asked what was so special about me that the kids saw me as a bigger authority than their own parents. My usual answer was that I try to be myself and see the world through a given kid's eyes to better understand them. I added that I could admit my own mistakes, ignorance and apologise. I never forced the children to anything - I merely encouraged and allowed them to make decisions and face the consequences of those decisions.

The author of those reflections (clearly forming her self-esteem) unfortunately also experienced another side of her profession. With disappointment, she adds the following: Unfortunately, my attitude to children and parents was not accepted by the head teacher and the management. I allowed the kids and parents from pathological families to feel needed, I organised collections of clothes and other things, I found sponsors so that they could get presents from Santa Claus and at Easter like all other kids; I also secured financing of a trip. I had a different view about the staff meeting where a decision was made that 6-year-old children would be examined in the head teacher's office by means of a timed reading comprehension test. This was one of numerous decisions which ignored the kids' needs 
and mental constitution. I turned out to be an inconvenient worker who dared to have critical opinions and fought for the kids - and so I had to leave this institution. Parents wrote letters to the school management, were gathering signatures in my defence, to let me stay. Unfortunately, the head teacher remained unfazed [...].

The remaining part of the presented autobiographical recollections reveals a less optimistic side of the functioning in the environment which not only fails to be nurturing and supporting, but is also destructive and discourages creative, committed pedagogical work.

I have worked at school for two years now - continues Justyna. Right now, I am a class teacher of the second grade. Last year, apart from the responsibilities of a class teacher, I also taught English in all classes within I-III grade scope. Despite the fact that I work in a Catholic school, I am disliked by the head teacher, because, above all, I focus on the good of the children and because numerous parents come to me with their problems and I can listen to them and understand. During my duty hours I am not only visited by the children's parents from my class, but also those from other classes. Many parents tried - after the first year - to transfer their children to my class, but the head teacher did not agree to that. For the past two years, the management has tried to mentally abuse me so that I would quit [...]. After some unsophisticated attacks directed at Justyna ${ }^{8}$, some positive situations also appeared. All parents backed me up and did not believe in some false accusations - she wrote on. I always harshly oppose whenever the kids are given negative grades for their behaviour [...], I defend children presenting tutoring problems. I am criticised that my class is undisciplined and disobedient in front of other teachers; I am never given any responsible task and I have to be at all other teachers' disposal. And whenever the tasks are distributed, the principal always makes a comment that whenever somebody is good for everything, they are good for nothing. It seems I am the person good for everything.

The young teacher goes on to declare: I never had any tutoring problems with pupils in any class whatsoever. I am well liked by the kids (in this case, it did not suffice as apparently the teacher was also supposed to earn the sympathy of the head teacher - E.M.), they frequently come to me to talk about their problems and what made them happy. This is what allows me to survive all the difficult moments and believe that this work is still worth doing; those kids trust me, often tell me that they love me and that I can't leave them. The author - although it may

8 There appears a motive of insinuations and accusations concerning the author's private life. 
be difficult to assess how self-conscious she is in stating this - seems to be providing a recipe for building teacher's authority in the following words: How did I manage to deserve all the authority in the eyes of my pupils? I believe that deep inside I am still a child - I haven't lost this specific kind of innocence - I approach everyone on an individual basis. I have time for everyone and I am able to understand, see the world through their eyes and maybe help them out in difficult situations. I never humiliate them and if I scold them for bad behaviour, it is only because I don't want them to repeat it. I never force them to do anything - I merely point to the right direction [...]. I can also acknowledge my mistakes or ignorance and apologise. My pupils know that they are my priority and I will never allow anybody to get hurt. At the same time, I am very demanding: responsibilities come first - only then there's time for pleasure. My pupils realise they do not learn for me, but for their own sake, and if there's a test - it is not organised in order to stress them out by showing their ignorance, but rather to provide them with orientation as to what they know and what needs additional work.

There is one final remark to complement this picture of the teaching path: I am hardly an ideal, I make mistakes, but I am able to own up to them. My pupils sometimes criticise me for my lack of consistency - for the fact that I am too lenient and provide too many opportunities. [...] My pupils also accept the fact that I openly admit I don't know something [... I happen to have a worse day and shout at them, but then I am able to stand in front of the class and apologise for my behaviour in accordance with our class regulations. [...].

How did I earn the acceptance of the parents? - asks the narrator and tries to answer -I think it was with my honesty, empathy, understanding and my love for their kids. In addition, it was the fact that I am demanding and I believe in their children... always trying to find time, a good word and a smile for each child...

N2: Another perspective of teachers' everyday life (Anna, 10 years of teaching experience, married with two children):

[...] I often wonder about the meaning of my work and the goals I want to achieve. My awareness of what is most essential in the field of educational work has been shaping for years. It resulted from diverse life experiences - initially as a child, then a teenager, and finally an adult. At work, however, my teaching approach is on numerous occasions modified by various educational situations, unique personalities of my pupils, parents' expectations or reforms of the educational system. [...] I feel job-related satisfaction when I see that the kids are happy - when they enter the classroom with a smile and grant me their child-like love. In such moments I get 
a bigger motivation, see meaning in the things I do and I feel that what I do constitutes a value in itself [...]. In order to teach children, a person must first know who they themselves are, what values they observe and what the most important things in life are. At my work, every single detail counts - each word, smile or gesture - the teacher wrote. Everything is noticed by children, causes a response in their psyche, inspires certain feelings, desires and interests. All the details shape their attitude towards learning, themselves, the others, and, obviously, myself. Respect cannot be forced in any way. One simply has to work hard for it. [...] For example, I'm a class teacher, but - simultaneously - a sort of a school mum, friend, nurse, confidante, psychologist or a therapist. My work demands a certain calling, it is a mission of sorts. To a large extent, it is me who influences what my pupils shall become in the future, their personality - and, as a consequence, the whole world. This huge responsibility makes me feel truly important and needed.

Every day, children spend approximately five full hours with me, which means that frequently I have a bigger opportunity to pass over certain values than their parents. In my daily work, I try to pay attention to my pupils' potential and talents. I realise that providing motivation is of huge importance, so I encourage the kids to participate in various competitions and contests so that they are able to develop their passions and keep discovering more and more skills. In addition, at least once a week I organise talks about what is appropriate and what is "frowned upon". It turns out that children are very perceptive in terms of recognizing those two categories of things, but lack of consistency in one's action leads to disorientation and a failure to observe rules. [...] Another important thing is being consistent also in one's own behaviour: if I don't permit my pupils to sit on desks, then I avoid doing it myself $[\ldots]$.

N3: The last narrator, whose reflections were used here to illustrate teachers' everyday experiences (Lucyna, 24 years of professional experience, married with three teenage children) gave her story the following title: My everyday teaching reality, as seen from the perspective of successes and failures.

[... I have worked in this profession for over 20 years and it was an entirely conscious decision to pick it. I love what I do and I can't see myself spending my life doing anything else professionally. Perhaps it sounds snobbish, but I will add that being a teacher is my calling. Obviously, I am delighted by all the successes of pupils I prepare for competitions, but I have always assumed that my skills are one thing, and whether my actions inspire anything is another. If we have this combination of my effort and pupils' potential - then we could have significant results. On the 
other hand, if the potential isn't there, then the success (in competitions etc.) isn't likely. [...] The author provides examples of such successes - although she is not sure whether she was a crucial part of them. I had a winner and finalists of a competition on the provincial level. Is that a success? I suppose it might be seen this way (the school is small, situated in a village, with few pupils), especially by others - since today only such successes are appreciated. And I simply believe that sometimes I am lucky to get very talented pupils, something that I take advantage of. However, what I personally consider my success is the fact that a girl with selective mutism who at the level of early school education completely failed to communicate with a teacher, after six months of working with me as a tutor, spoke to me and was convinced to participate in a school academy where she - in a loud and clear fashion - recited a poem for her grandmother. What was even more touching - the same pupil, upon completion of the lower-secondary school, came to me with a flower and thanked me for my support and help with a beautiful, musical voice. The very fact that that pupil chose to ask me for help was my personal success in itself - regardless of sneers of other teachers who typically comment that I am naive and easy to manipulate.

Such examples are easy for me to provide - emphasises Lucyna - as they are, I suppose, for other teachers. They are what makes us keep trying - what makes us see the meaning in what we do: despite all obstacles. I can also say, in all honesty, that even though I treat my achievements as minor ones, it was obviously very nice for other people to take note of them and report to proper authorities after which I was awarded the title of "The best teacher in the commune" or when I received the Medal of the National Education Commission for special achievements for education and upbringing. The above-mentioned expectations stated by this teacher - for authorities to show appreciation for good educators - are worth emphasising.

Next to such small joys which strongly motivate me to work harder - there are also failures. Fortunately, they also motivate me instead of discouraging. Those failures cause that I do not succumb to routine as they force me to wonder where I made a mistake. What do I have to change? How can I better approach a given child? My biggest failure happened when I got another so-called "difficult" class to look after as a class tutor. For two years, I tried to reach to them, change their attitude to school duties, improve the attendance rate and change their behaviour. During the third year of work with this class, I "surrendered" and functioned only to "survive" (as everything I did to improve the situation failed anyway). The thing 
was: their behaviour suddenly became much worse. This was when I realised that my former efforts were meaningful and brought effects... simply those effects did not meet my predetermined expectations. As a result, I saw them as failures while in reality those were (small, but still...) successes. This experience taught me the important lesson that us, educators, can never give up - and when I got yet another "difficult" class - I organised my efforts in such a way that I was at least able to change the pupils' attitude towards learning which eventually found an effect of the highest results in the whole commune in the area of tests in the sixth grade. As it turned out, in this case a failure was a road sign pointing to a future success. It is a constructive example of learning through experience and an argument in favour of analysing one's own actions in order to draw from them our "educational wisdom".

To sum up, out of necessity, those brief fragments of narration treated here merely as reflections of everyday life, let us use words of Lucyna who wrote the following: [...] our everyday teaching reality - frequently referred to as grey in my personal view is quite colourful. We work with young, often small people who are live creatures, which means that they are quite unpredictable. I can never be sure what is going to happen when I go to work. Pupils are impossible to classify: they are spontaneous, sincere, creative and demand from teachers constant readiness to act. While engaging in this work, we optimistically hope that our work is going to end up with a success. However, we cannot assume that we shall always avoid failure as pupils are impossible to be programmed like computers [... ]. It is important, though, not to be discouraged by failures, not to break down or give up. We should always draw new conclusions and try once again. [...] A teacher who is conscious of his calling and the meaning of what he does has a decisive impact on the most crucial factors of potential success: the growth of his personality and proper shaping of his relations with pupils.

I have a sound reason to believe that in the above-mentioned everyday experiences we can sometimes find more truth about us - teachers - than in numerous textbooks with applicable theories. "Reading" those narrations generated by teachers is also a way of learning how to be a teacher, how to draw pleasure from tiny successes and build the feeling that it was worthwhile to enter the teachers' world. 


\section{CONCLUSION}

It is obvious that research grounded in the current of qualitative strategies and especially presentation of only selected exemplifications of autobiographical narrations - regarding teachers' everyday professional reality, can hardly authorise the researcher to form generalisations or conclusions concerning "typical" paths of teachers' professional functioning. Their cognitive value, to my mind, consists in the possibility to confront normative "role models" with practical, everyday exemplifications of this role. In addition, teachers - by presenting their own ways of perceiving and understanding the educational process - encourage us to pose valid questions and search for answers. They are allowed to "discover" what defines their everyday reality and reach to its dimensions that are frequently difficult to notice - not to mention to reflect upon the sense of the undertaken efforts and to assign meanings. In this fashion, teachers gain a greater chance to become co-creators and not merely "consumers" of educational knowledge. It is a way of teachers' development in the process of one's own formation in this profession, as well as "a kind of a bridge connecting fragments of their understood and experienced educational reality with the ones they are in the process of discovering" (Adamska-Staroń, M. Piasecka, B. Łukasik, 2007, p. 88). Those narrations allow for an opportunity to join this metaphorical journey of reading and interpreting "the message" resulting from their reflection concerning the chosen profession and their own feelings; they are, on the one hand, a testament to a diversity of educational paths and, on the other hand, to a richness of experienced emotions requiring the effort of discovering. One needs to emphasise, however, that the narrative current of pedeutological research is merely one of many perspectives of describing the teachers' worlds, one of many propositions of "cognitive familiarisation of teachers' everyday reality", one of many possible narrations concerning teaching. Through such an analysis of teachers' autobiographic narrations, we can attempt to recognise the rhythm of their work and life, search for the answer to the questions of what experiences, feelings and emotions rule their everyday reality. On the one hand, we can realise the alarming diversity of teachers' worlds and the richness of meanings with which the world is described. On the other hand, there appears a temptation to recognise individual biographies, their life stories, subjective visions of the world in order to better understand, teach and support more effectively and search for answers which 
are not only limited to the question of what the situation should be like in the future, but also what it is like right now, and what the people directly involved in this reality - teachers themselves - think about it.

\section{REFERENCES:}

ADAMSKA-STAROŃ, M., Piasecka, M, Łukasik, M.B. (2007), Inny sposób myślenia o edukacji. Metaforyczne narracje, Oficyna Wydawnicza „Impuls”, Kraków.

BHASKAR, R. (2002), Reflection on meta-reality. Transcendence, emancipation and everyday life, Sage, New Delhi - Thousand Oaks - London.

CZEREPANIAK-WALCZAK, M. (2010), Emancypacja $w$ codzienności i przez codzienność. Egzemplifikacje edukacyjne, [in:] Wychowanie. Pojęcia - procesy - konteksty. Interdyscyplinarne ujęcie, vol. 5, Codzienność w szkole. Szkoła w codzienności, M. Dudzikowa, M. Czerepaniak-Walczak (eds.), GWP, Gdańsk.

GIDDENS, A. (2003), Stanowienie społeczeństwa. Zarys teorii strukturacji, translated by S. Amsterdamski, Zysk i S-ka, Poznań.

MALINOWSKA, J., Jabłońska, M. (2010), Myślenie o nauczycielu i jego edukacji. Z rekonstrukcji światów edukacyjnych nauczycieli nauczycieli, Oficyna Wydawnicza ATUT - Wrocławskie Wydawnictwo Oświatowe, Wrocław.

MURAWSKA, E. (2013), Nauczycielska (nie)codzienność. Mikrospojrzenie w makrosprawach [in:] I. Surina, E. Murawska, D. Apanel, G. Durka (eds.), Edukacja w obliczu przemian społecznych, Wydawnictwo Adam Marszałek, Torun.

MURAWSKA, E. (2014), Barwy nauczycielskiej codzienności, [in:] Codzienność szkoły. Nauczyciel, J.M. Łukasik, I. Nowosad, M.J. Szymański (eds.), Oficyna Wydawnicza „Impuls”, Kraków.

NOWAK-DZIEMIANOWICZ, M. (2012), Edukacja i wychowanie $w$ dyskursie nauki i codzienności, Oficyna Wydawnicza „Impuls”, Kraków.

OLEJNICZAK, M. (2009), Nauczyciel wobec wyzwań kultury popularnej, [in:] Nauczyciele wobec wyzwań wspótczesności. Doświadczenia - badania - koncepcje, E. Przygońska, I. Chmielewska, (eds.) Wydawnictwo WSH-E, Łódź.

RITZER, G. (2004), Klasyczna teoria socjologiczna, translated by: H. Jankowska, Wydawnictwo Zysk i S-ka, Poznań.

RUTKOWIAK, J. (2003), Święto i codzienność wobec idei społeczeństwa uczacego się, „Teraźniejszość - Człowiek - Edukacja” 2003, special issue.

SCHÜTZ, A. (1984), Potoczna i naukowa interpretacja ludzkiego działania, [in:] Kryzys i schizma, selection and introduction, E. Mokrzycki, vol 1, PIW, Warszawa. 
SCHÜTZ, A. (2008), O wielości światów. Szkice z socjologii fenomenologicznej, translated by: P.M. Senge, „Nomos”, Kraków.

TOMASZEWSKA, A. (2009), Nauczyciel na miarę XXI wieku, [in:] Nauczyciele wobec wyzwań wspótczesności. Doświadczenia - badania - koncepcje, E. Przygońska, I. Chmielewska, (eds.) Wydawnictwo WSH-E, Łódź.

WEBER, M. (1985), "Obiektywność" poznania w naukach społecznych, [in:] Problemy socjologii wiedzy, A. Chmielecki, (ed.), translated by: A. Chmielecki, S. Czerniak, J. Niżnik, PWN, Warszawa. 